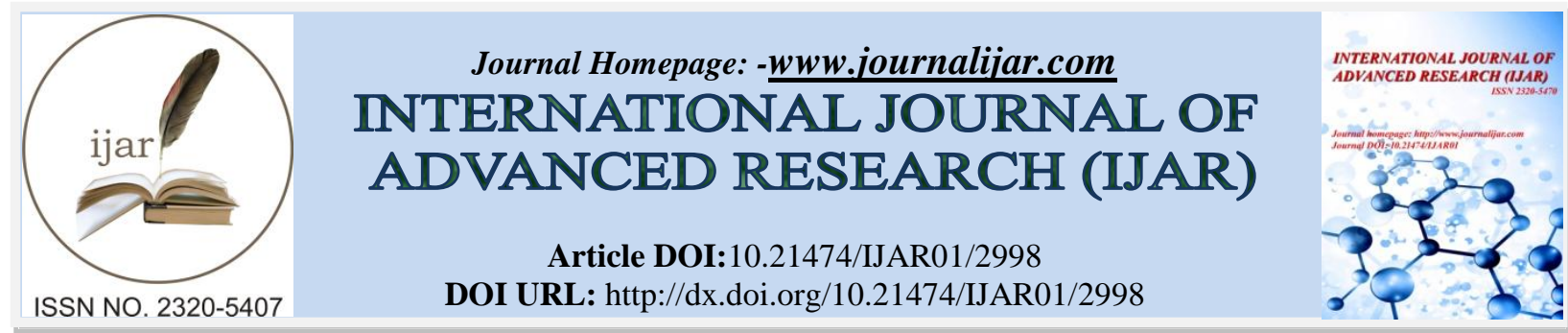

RESEARCH ARTICLE

\title{
IS TIME MANAGEMENT RELATED TO BETTER ACADEMIC PERFORMANCE AND PERCEIVED ACADEMIC SATISFACTION AMONG MEDICAL STUDENTS? A CROSS- SECTIONAL SURVEY IN SAUDI ARABIA.
}

\author{
Hamoud Mohammed Alshaya', Mudassar Ali Roomi ${ }^{2}$, Mohammed Amouri Alzayer ${ }^{3}$, Saad Khaleel Alonze ${ }^{4}$ \\ and Rakan Fahad Alshaalan ${ }^{4}$ \\ 1. MBBS, Intern Alzulfi General Hospital, Saudi Arabia. \\ 2. M.Phil. Physiology,Assistant Professor in Physiology, School of Health Sciences, College of Medicine, Nursing \\ and Health Sciences, Fiji National University, Fiji Islands. \\ 3. MBBS, Qatif Central Hospital, Qatif, Saudi Arabia. \\ 4. MBBS, King Fahad Medical City, Riyadh, Saudi Arabia.
}

\section{Manuscript Info}

\section{Manuscript History}

Received: 28 November 2016

Final Accepted: 27 December 2016

Published: January 2017

Key words:-

Self-management, Academic

Achievement, Grade Point Average,

Prioritization, Procrastination,

University Students

\section{Abstract}

Background: Time management skill is considered very important for academic success and better quality of life. We aimed to investigate time management in Saudi medical students, and to explore relationship between these skills and socio-demographic features of participants and parameters of academic performance.

Methods: This cross-sectional survey was conducted in January 2017 using a self-administered questionnaire. Data were entered and analyzed using IBM-SPSS-20. Data were summarized and analyzed by using frequencies and percentages. Chi-square was used to test associations between time management and socio-demographic features. Pearson correlation was used to measure correlations between time management and parameters of academic performance.

Results: A total of 89 participants (37.1\% males, $62.9 \%$ females) aged23 \pm 2.44 (19-29) years participated in this study. Adequate and inadequate time management wasfound in $46 \%$ and $54 \%$ of the participants, respectively. There was no significant difference of time management in participants on the basis of their gender, study in private or government colleges, residence, rural or urban background, and educational qualification of their parents.More pre-clinical students had adequate time management than clinical students $(p=0.019)$. Significant positive correlationswere observed between time management and total percentage of marks in last exam $(\mathrm{r}=0.331$, $p=0.019)$, and perceived academic satisfaction ( $\mathrm{r}=0.356, p=0.001$ ).

Conclusions:More than half participantshad inadequate time management. There was no difference of time management on the basis of most of thesocio-demographic features. Pre-clinical students seemed to manage their time better than clinical students. Time management is positively correlated with total percentage of marks in last exam, and perceived academic satisfaction. Students should increase their time management skills by reading books on this topic and attending relevant trainings and counseling sessions. 


\section{Introduction:-}

Time management has been referred to as set of principles, practices and skills which enable a person to get things done by working smarter but not harder. Effective time management techniques help us to judiciously organize and plan time which we spend on various activities with the aim to increase productivity and quality of life, even when time is less and pressures are high (MindTools.com, 2017). Time management is an acquired skill which can be developed at any age to perform actions efficiently. It has been observed that there are some people who find that they have enough time for their daily activities, but some people struggle as they rush from one task to another without finishing anything. It is not because former type of people have more time but because they know how to use their time effectively by practicing good time management skills(SkillsYouNeed, 2017).

Time management is actually self-management. Time management cannot increase the amount of time we have in aday but it can bring a better life for us by making us more organized(Misra and McKean, 2000).One can enjoy his life by sparing and devoting more time for himself, for his family, relatives and friends; effective time management can enables us to do so(Efil I., 2007).

Currently, time management is considered a very important element for personal and corporate success especially in the professional environment (Koch, 1998). A study by Khatib (2014) has explored that effective time management is associated with higher academic performance, while poor time management in students is associated with higher perceived stress. Being unable to plan and use time properly and doing last-minute study for exams are some factors that can increase stress among students leading to poor academic performance (Britton and Tesser, 1991).

Sometimes, time wasting factors in schools can be external issues which suddenly come up e.g. unplanned events, strikes, accidents, emergencies. These issues can affect students' studies adversely. Students usually have less control on these unforeseen issues (Achunine and Irondi, 1998). However, the internal time wasting factors of students can be even more important than the external factors. Some of these factors are lack of prioritization, procrastination and distractions. Some students may be overwhelmed by the task and they put it off till later dates. This procrastination is due to habitual laziness. It does not let us complete the task rather it brings more tension. Procrastination and lack of prioritization are two most important problems among students. Lack of time management skills can lead to procrastination especially when students don't meet the deadlines. Distractions, while studying, can also waste students' time. Some students may be distracted as they wrongly feel that some unrelated and unimportant things need their urgent attention (King, 2002). This may happen when students have heaps of work to be done and they are lazily looking for an appropriate time to study.

It has been observed that medical students have vast curriculum. It may be difficult for some of them to manage their study and leisure time which may lead to stress (Stecker, 2004; Yousafzai et al., 2009; Waghachavare et al., 2013; Obokoet al., 2015). This further increases the importance of time management skills for medical students. There seem to be dearth of evidence on time management skills, academic performance and perceived academic satisfaction among Saudi medical students. Therefore, this study was conducted to: a) assess time management skills of Saudi medical students, b) investigate association between socio-demographic features of the participants and their time management skills, and c) explore correlation between total time management score and various parameters of academic performance of the participants.

\section{Methodology:-}

This study was a cross-sectional survey conducted in January 2017 among male and female medical students enrolled in various medical colleges of Saudi Arabia. The participants were aged $\geq 19$ years and were studying in various years of MBBS from year 1 through 6.An online structured questionnaire was prepared for this survey using Google Forms. This self-administered questionnaire contained two sections. Section 1 consisted of information on socio-demographic features (age, gender, residence, parent's highest qualification etc.), academic performance and perceived academic satisfaction of the participants. Information was obtained on the following parameters of academic performance: GPA of last year, total percentage of marks in last exam, total number of A/A+ grades in last exam, total number of supplementary/failures in last exam, cumulative percentage of attendance during last year/semester, and total number of workshops/seminars/conferences attended during last one year. Information on parameters of academic performance was self-reported by the participants and was not confirmed from academic 
records of the medical colleges. Students were requested to describe their perceived academic satisfaction on a scale of 1-10 with 10 being the most positive. Section 2 comprised of 25 standard questions to collect information on time management skills of the participants; this section was taken from the website of Wayne State University(2013).

Information on participants' age, gender, year of study during MBBS, type of medical college whether government or private, residence during study, permanent residence, highest qualification of father and mother were obtained. Students of 1-3 and 4-6 years of MBBS were considered in pre-clinical and clinical years, respectively. Each participant was supposed to answer each of the 25 standard questions of time management questionnaire. Participants' were to respond each question as 'always' or 'sometimes' or 'never'. 'Always' carried 2 scores, 'sometimes' carried 1 score and 'never' carried 0 score. For each participant, scores of all 25 questions were added up. Maximum scores that a participant could have achieved for 25 questions on time management were 50. A participant with a score of $\leq 29$ was considered to have inadequate time management skills. A total score of $\geq 30$ meant that the participant had adequate time management skills.

We informed all the participants about the purpose and scope of this survey before their voluntarily participation. We ensured anonymity and confidentiality of all the data. Furthermore, we considered various ethical aspects in line with Helsinki Declaration.

Data of only those participants ( $\mathrm{n}=89$ ) who filled the questionnaire properly were subject to analysis. Data on sociodemographic features of the participants, and their responses to all 25 standard questions on time management were entered and analyzed using IBM Statistical Package for Social Sciences (SPSS) version 20. The data were cross checked to ensure accuracy. Categorical data were summarized as frequencies and percentages. Chi-square test was used to measure association between each of the socio-demographic features of participants and their time management skills. Pearson correlation was used to test correlation between total time management score of the participants and other academic parameters (e.g. GPA, grades, supplementary/failures, academic satisfaction etc.). A $p$-value of $\leq 0.05$ was considered statistically significant.

\section{Results:-}

A total of 89 participants (37.1\% males, $62.9 \%$ females) with age of $23 \pm 2.44$ (19-29) years participated in this study. More than half (61.8\%) of participants were students of clinical (4-6) years and the rest (38.2\%) were students of pre-clinical (1-3) years of MBBS. Majority (86.5\%) of the students were studying in government medical colleges. Most $(85.4 \%)$ of the students were living in their homes (day scholars) and the rest of the students were living in hostels. Permanent residence of almost three-fourths of participants was in urban areas. Highest qualification of father and mother was at least secondary school education for $89.9 \%$ and $77.5 \%$ of total participants, respectively (Table 1).

Cumulative responses of the participants to each question of the time management questionnaire are given in Table 2. Most of the participants had less scores for questions No. 4, 13, 18, 20 and 21 of the questionnaire. However, participant got generally good scores for questions No. 1, 3, 6, 7, 17, 23 and 24. Mean time management score was 27.91 \pm 8.56 (range: $9-50$ ).

Adequate time management skills (score $\geq 30$ ) were found in $46 \%$ of the participants while inadequate time management (score $\leq 29$ ) was observed in $54 \%$ of the participants (Figure).

Association between socio-demographic characteristics and time management skills of the participants is presented in Table 3. There was no significant difference of time management skills between male and female participants, students of private and government medical colleges, students living in hostels and homes, and rural versus urban students. Moreover, there was no statistically significant difference of time management skills between participants when we compared them on the basis of highest educational qualification of their parents. Adequate time management skills were present in $61.8 \%$ of pre-clinical students as compared to $36.4 \%$ of clinical students. Moreover, time management skills were inadequate in $38.2 \%$ of pre-clinical students as compared to $63.6 \%$ of clinical students. In a nutshell, pre-clinical students had significantly higher time management skills as compared to clinical students $(p=0.019)$.

Pearson correlation between total time management score and parameters of academic performance are given in Table 4. Significant positive correlations were observed between total time management score and total percentage 
of the marks of last exam $(\mathrm{r}=0.331, p=0.019)$, and perceived academic satisfaction $(\mathrm{r}=0.356, p=0.001)$. Moreover, we found significant positive correlations between academic satisfaction and GPA of the last year/semester $(\mathrm{r}=$ $0.290, p=0.016)$, total percentage of the result of last exam $(\mathrm{r}=0.390, p=0.006)$, and total number of $\mathrm{A} / \mathrm{A}+$ grades in last exam $(\mathrm{r}=0.340, p=0.002)$. No significant correlation was observed between total time management score and other academic parameters of the participants.

Table 1:-Socio-demographic characteristics of the participants $(n=89)$

\begin{tabular}{|c|c|}
\hline Socio-demographic Characteristics & Frequency $(\%)$ \\
\hline Age: Mean \pm SD (Range) & $23 \pm 2.44(19-29)$ years \\
\hline \multicolumn{2}{|l|}{ Gender } \\
\hline Female & $56(62.9 \%)$ \\
\hline Male & $33(37.1 \%)$ \\
\hline \multicolumn{2}{|l|}{ Year of study during MBBS } \\
\hline 1 & $4(4.5 \%)$ \\
\hline 2 & $9(10.1 \%)$ \\
\hline 3 & $21(23.6 \%)$ \\
\hline 4 & $12(13.5 \%)$ \\
\hline 5 & $12(13.5 \%)$ \\
\hline 6 & $31(34.8 \%)$ \\
\hline \multicolumn{2}{|l|}{ Pre-clinical or clinical students } \\
\hline Students of pre-clinical (1-3) years & $34(38.2 \%)$ \\
\hline Students of clinical (4-6) years & $55(61.8 \%)$ \\
\hline \multicolumn{2}{|l|}{ Type of medical college } \\
\hline Private & $12(13.5 \%)$ \\
\hline Government & $77(86.5 \%)$ \\
\hline \multicolumn{2}{|l|}{ Residence during study } \\
\hline Living in the hostel & $13(14.6 \%)$ \\
\hline Living in your own home (day scholar) & $76(85.4 \%)$ \\
\hline \multicolumn{2}{|l|}{ Permanent Residence } \\
\hline Rural area & $25(28.7 \%)$ \\
\hline Urban area & $62(71.3 \%)$ \\
\hline \multicolumn{2}{|l|}{ Highest qualification of Father } \\
\hline Primary & $9(10.1 \%)$ \\
\hline Secondary & $11(12.4 \%)$ \\
\hline Tertiary & $69(77.5 \%)$ \\
\hline \multicolumn{2}{|l|}{ Highest qualification of Mother } \\
\hline Primary & $20(22.5 \%)$ \\
\hline Secondary & $8(9.0 \%)$ \\
\hline Tertiary & $61(68.5 \%)$ \\
\hline
\end{tabular}

Table 2:- Participants' cumulative responses to each question of the time management questionnaire

\begin{tabular}{|l|c|c|c|c|}
\hline \multirow{2}{*}{ Questions } & \multicolumn{2}{c|}{$\begin{array}{c}\text { Participants' Responses } \\
\text { n (\%) }\end{array}$} & $\begin{array}{c}\text { Total } \\
\text { responses } \\
\text { from the } \\
\text { participants }\end{array}$ \\
\cline { 3 - 5 } & Never & Sometimes & Always & 89 \\
\hline $1 . \quad$ I do things in order of priority. & $5(5.6 \%)$ & $44(49.4 \%)$ & $40(44.9 \%)$ & \\
\hline $\begin{array}{l}2 . \\
\text { I accomplish what needs to be done during the } \\
\text { day. }\end{array}$ & $6(6.7 \%)$ & $61(68.5 \%)$ & $22(24.7 \%)$ & 89 \\
\hline $3 . \quad$ I always get assignments done on time. & $3(3.4 \%)$ & $37(41.6 \%)$ & $49(55.1 \%)$ & 89 \\
\hline
\end{tabular}




\begin{tabular}{|c|c|c|c|c|}
\hline 4. I feel I use my time effectively. & $\begin{array}{c}29 \\
(32.6 \%)\end{array}$ & $49(55.1 \%)$ & $11(12.4 \%)$ & 89 \\
\hline $\begin{array}{l}\text { 5. I tackle difficult or unpleasant tasks without } \\
\text { procrastinating (delaying) }\end{array}$ & $15(16.9 \%)$ & $57(64.0 \%)$ & $17(19.1 \%)$ & 89 \\
\hline 6. I force myself to make time for planning. & $7(7.9 \%)$ & $42(47.2 \%)$ & $40(44.9 \%)$ & 89 \\
\hline 7. I am spending enough time planning. & $\begin{array}{c}11 \\
(12.4 \%)\end{array}$ & $37(41.6 \%)$ & $41(46.1 \%)$ & 89 \\
\hline 8. I prepare a daily or weekly "to-do" list. & $\begin{array}{c}17 \\
(19.1 \%)\end{array}$ & $40(44.9 \%)$ & $32(36.0 \%)$ & 89 \\
\hline $\begin{array}{l}\text { 9. I prioritize my list in order of importance, not } \\
\text { urgency. }\end{array}$ & $\begin{array}{c}14 \\
(15.9 \%)\end{array}$ & $44(50.0 \%)$ & $30(34.1 \%)$ & 88 \\
\hline $\begin{array}{l}\text { 10. I am able to meet deadlines without rushing at } \\
\text { the last minute. }\end{array}$ & $\begin{array}{c}21 \\
(24.1 \%)\end{array}$ & $45(51.7 \%)$ & $21(24.1 \%)$ & 87 \\
\hline $\begin{array}{l}\text { 11. I keep up-to-date on my reading and homework } \\
\text { assignments. }\end{array}$ & $\begin{array}{c}14 \\
(16.1 \%)\end{array}$ & $48(55.2 \%)$ & $25(28.7 \%)$ & 87 \\
\hline $\begin{array}{l}\text { 12. I prevent interruptions from distracting me } \\
\text { from high priority tasks. }\end{array}$ & $\begin{array}{c}14 \\
(15.9 \%)\end{array}$ & $53(60.2 \%)$ & $21(23.9 \%)$ & 88 \\
\hline $\begin{array}{l}\text { 13. I avoid spending too much time on trivial/small } \\
\text { matters. }\end{array}$ & $\begin{array}{c}15 \\
(17.0 \%)\end{array}$ & $59(67.0 \%)$ & $14(15.9 \%)$ & 88 \\
\hline $\begin{array}{l}\text { 14. I am spending enough time on academic } \\
\text { matters. }\end{array}$ & $\begin{array}{c}14 \\
(16.1 \%)\end{array}$ & $41(47.1 \%)$ & $32(36.8 \%)$ & 87 \\
\hline $\begin{array}{l}\text { 15. I plan time to relax and be with friends in my } \\
\text { weekly schedule. }\end{array}$ & $\begin{array}{c}21 \\
(24.1 \%) \\
\end{array}$ & $32(36.8 \%)$ & $34(39.1 \%)$ & 87 \\
\hline $\begin{array}{l}\text { 16. I have a weekly schedule on which I record } \\
\text { fixed commitments such as classes and work } \\
\text { hours. }\end{array}$ & $\begin{array}{c}26 \\
(29.5 \%)\end{array}$ & $42(47.7 \%)$ & $20(22.7 \%)$ & 88 \\
\hline $\begin{array}{l}\text { 17. I try to do the most important tasks during my } \\
\text { most energetic periods of the day. }\end{array}$ & $9(10.2 \%)$ & $43(48.9 \%)$ & $36(40.9 \%)$ & 88 \\
\hline $\begin{array}{l}\text { 18. I make constructive use of my commuting } \\
\text { (travelling) time. }\end{array}$ & $\begin{array}{c}18 \\
(20.5 \%)\end{array}$ & $59(67.0 \%)$ & $11(12.5 \%)$ & 88 \\
\hline $\begin{array}{l}\text { 19. I periodically re-assess my activities in relation } \\
\text { to my goals. }\end{array}$ & $\begin{array}{c}12 \\
(13.8 \%)\end{array}$ & $47(54.0 \%)$ & $28(32.2 \%)$ & 87 \\
\hline $\begin{array}{l}\text { 20. I have discontinued any wasteful or } \\
\text { unprofitable activities or routines. }\end{array}$ & $\begin{array}{c}18 \\
(20.5 \%)\end{array}$ & $56(63.6 \%)$ & $14(15.9 \%)$ & 88 \\
\hline $\begin{array}{l}\text { 21. I screen and group my telephone calls to allow } \\
\text { for control over telephone interruptions. }\end{array}$ & $\begin{array}{c}36 \\
(40.9 \%)\end{array}$ & $41(46.6 \%)$ & $11(12.5 \%)$ & 88 \\
\hline $\begin{array}{l}\text { 22. I judge myself by accomplishment of tasks } \\
\text { rather than by amount of activity or "busy- } \\
\text { ness". }\end{array}$ & $\begin{array}{c}12 \\
(13.6 \%)\end{array}$ & $51(58.0 \%)$ & $25(28.4 \%)$ & 88 \\
\hline $\begin{array}{l}\text { 23. My actions are determined primarily by me, } \\
\text { not by circumstances or by other people's } \\
\text { priorities. }\end{array}$ & $8(9.1 \%)$ & $42(47.7 \%)$ & $38(43.2 \%)$ & 88 \\
\hline $\begin{array}{l}\text { 24. I have a clear idea of what I want to } \\
\text { accomplish during the coming semester. }\end{array}$ & $11(12.5 \%)$ & $41(46.6 \%)$ & $36(40.9 \%)$ & 88 \\
\hline 25. I am satisfied with the way I use my time. & $33(37.5 \%)$ & $33(37.5 \%)$ & $22(25.0 \%)$ & 88 \\
\hline
\end{tabular}


Figure: Percentage of the total participants showing adequate and inadequate time management

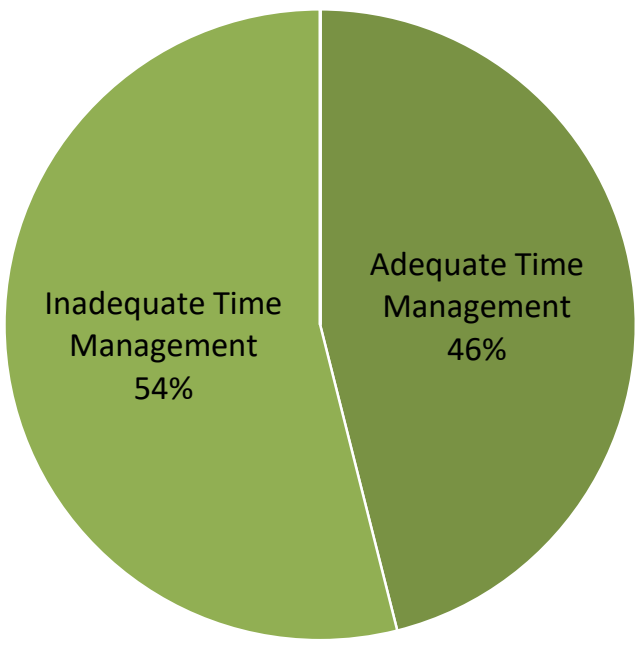

\author{
- Adequate Time \\ Management \\ - Inadequate Time \\ Management
}

Table 3:- Association between socio-demographic characteristics and time management skills of the participants

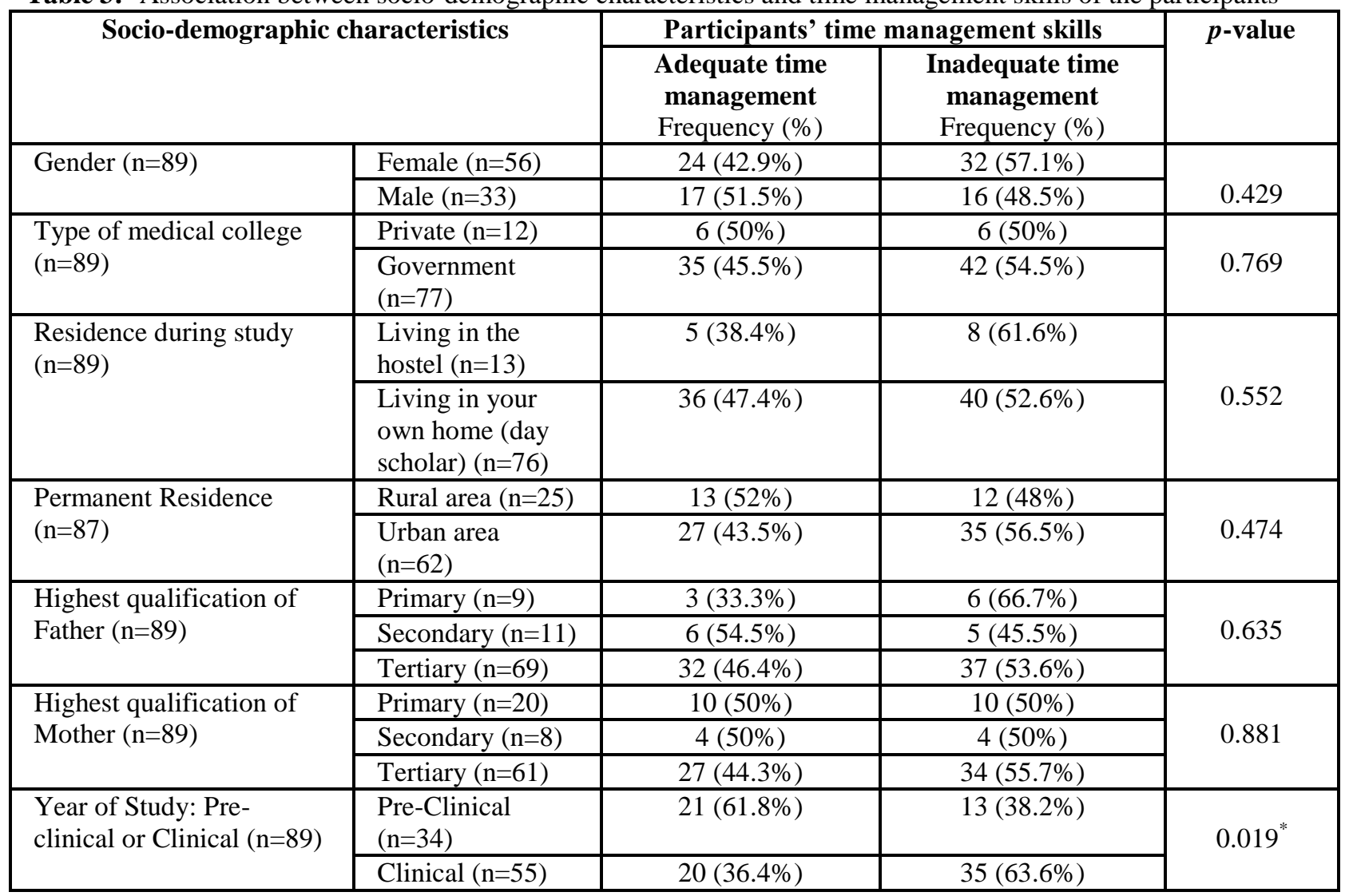

$* p \leq 0.05$ was considered statistically significant 
Table 4:-Correlation between total time management scores and parameters of academic performance

\begin{tabular}{|l|c|c|}
\hline \multicolumn{1}{|c|}{ Parameters of academic performance } & Pearson correlation coefficient(r) & $p$-value \\
\hline $\begin{array}{l}\text { GPA of the last year/semester } \\
(\mathrm{n}=69)\end{array}$ & 0.224 & 0.064 \\
\hline $\begin{array}{l}\text { Total percentage of the marks of last exam } \\
(\mathrm{n}=50)\end{array}$ & 0.331 & $0.019^{*}$ \\
\hline $\begin{array}{l}\text { Total number of A/A+ grades in last exam } \\
(\mathrm{n}=83)\end{array}$ & 0.203 & 0.066 \\
\hline $\begin{array}{l}\text { Total number of supplementary/failures in last } \\
\text { exam } \\
(\mathrm{n}=87)\end{array}$ & 0.006 & 0.955 \\
\hline $\begin{array}{l}\text { Cumulative Percentage of attendance in last } \\
\text { year/semester of study } \\
(\mathrm{n}=67)\end{array}$ & 0.052 & 0.678 \\
\hline $\begin{array}{l}\text { Total number of } \\
\text { workshops/seminars/conferences attended } \\
\text { during last one year } \\
\mathrm{n}=84)\end{array}$ & 0.016 & 0.883 \\
\hline $\begin{array}{l}\text { Perceived academic satisfaction } \\
(\mathrm{n}=88)\end{array}$ & & $0.001^{*}$ \\
\hline
\end{tabular}

$* p \leq 0.05$ was considered statistically significant

\section{Discussion:-}

Findings from this study suggest that more than half (54\%) of the Saudi medical students have inadequate time management skills. We also found that there is no significant difference of time management skills in the participants on the basis of their gender, their study in private or government medical colleges, their residence in hostels or homes, their rural or urban background, and the educational qualification of their parents. Furthermore, we found that pre-clinical students are more likely to have adequate time management skills as compared to clinical students. We also observed significant positive correlation between total time management scores and total percentage of the marks of last exam, and perceived academic satisfaction among the participants.

We have observed that $54 \%$ of the medical students in Saudi Arabia have inadequate skills to manage their time effectively. This means that almost every one out of two medical students in Saudi Arabia seem not using his/her time smartly. This also means that time management is one of the self-management skills that some students are better at than others. In another study carried out byEid et al. (2015)on nursing students in Egypt, it was explored that $85.5 \%$ of the nursing students have good time management skills while $14.5 \%$ have inadequate time management skills. This difference in findings of the two studies may be due to use of different questionnaires for assessing time management skills. Moreover, the participants in our study were medical students while in the Egyptian studywere nursing students. An implication of poor time management among nearly half medical students in our study is that they are at risk of psychological stress and poor academic achievement as is mentioned by Khatib(2014).

In our study, there is no significant difference between males and females on the basis of their time management skills which is similar to the findings of some other studies (Jahanseir,et al., 2008; Saketi and Taheri, 2010; Pehlivan, 2013; Adebayo, 2015). This means that both males and females may behave similarly to manage their time and similar importance should be given to both the genders during trainings on time management skills. However, in contrast to our findings, another study(Liu et al., 2009)has demonstrated that females have better time management skills than males. While some studies (Guoging and Yongxin, 2000; Macan et al., 2010)have reported that males have better time management than females.

Furthermore, we have observed that there is no significant difference in time management skills in our participants whether they are studying in private or government medical colleges, living in hostels or their homes, coming from rural or urban background, and having different educational qualifications of their parents. Its implication for academic counselors may be that, during teaching and training students on time management skills, equal importance should be given to all the students irrespective of their socio-demographic differences. 
We found that pre-clinical (year 1-3)students are better than clinical (year 4-6) students on the basis of their time management skills. One possible explanation for this can be that medical students are at risk of psychological stress during their transition from pre-clinical years to clinical years (Obokoet al., 2015). This increase in stress may be due to relatively more burden of studies during clinical years and may also affect the time management behavior of the students.

We have observed significant positive correlations between total time management scores and total percentage of the marks of last exam, and perceived academic satisfaction among the participant. It means that the students who can better manage their time might also get better results and may be more satisfied than their counterparts who are poor at time management. Moreover, no significant correlation was observed between total time management scores and GPA of the last year/semester. This finding is similar to the results of some other studies (Pehlivan, 2013; Eid et al., 2015).In contrast to our finding, some other studies (Proctor et al., 2006; Anand, 2007; Indreica et al., 2011; Khatib, 2014)have reported significant positive correlation between time management skills and GPA. This difference may be due to difference in sample size and also because students in all these studies were enrolled in dissimilar programs.

Moreover, we have found significant positive correlations between academic satisfaction and GPA of the last year/semester, total percentage of the marks of the last exam, and total number of A/A+ grades in the last exam. This means that the medical students who get a higher GPA, better percentage of result, and more A/A+ grades can be more satisfied than the students who are performing poorly in all of these parameters of academic performance.

One of the strengths of this study is that we have investigated association between time management skills and various socio-demographic features of the participants by using a standardized time management questionnaire developed by Wayne State University(2013).Furthermore, we have also studied correlations between total time management scores and various parameters of academic performance of the participants. One of the limitations may be relatively small sample size $(n=89)$ as compared to other similar studies. Caution must be taken to generalize the findings of this study due to its cross-sectional nature. We have used a self-administered questionnaire that may lead to some possibility of reporting bias.

\section{Conclusions:-}

This study has shown that more than half medical students of Saudi Arabia have inadequate time management skills. There is no difference of time management skills among the participants on the basis of most of their sociodemographic features. Pre-clinical students seem to manage their time better than clinical students. Time management is positively correlated with total percentage of marks in the last exam and perceived academic satisfaction.

Since, a big proportion of medical students has reported inadequate time management and later is also correlated with some parameters of academic performance, we recommend some implications of this study for students, teachers and academic counselors. Students should increase their time management skills by reading books and other literature on this topic, and by attending relevant seminars and workshops. Teachers should act as role model to encourage students' participation in such activities. Academic counselors and psychologists should help the students by providing counseling sessions on time management and by organizing trainings on time management skills. It is also recommended to include the topic of time management in the courses of higher secondary education and university education so that by learning and using these skills student may improve their academic performance and quality of their life.

Further studies are recommended to investigate relation between time management skills of the students and psychological stress. Moreover, prospective studies may also be conducted to assess long-term effects of time management skills on various parameters of academic performance of students.

\section{References:-}

1. Achunine, R.N. and Irondi, E. (1998) Management Administration of secondary education in Nigeria.Lagos: Totan Publishers Limited.

2. Adebayo,F. A. (2015). Time Management and Students Academic Performance in Higher Institutions, Nigeria - A Case Study of Ekiti State. International Research in Education, 3(2): 1-12. doi: 10.5296/ire.v3i2.7126. 
3. Anand, V. (2007). A study of time management: The correlation betweenvideo game usage and academic performance markers. Cyberpsychology \& Behavior, 10(4): 552-559.

4. Britton, B. K. and Tesser, A. (1991). Effects of time-management practices on college grades. Journal of Educational Psychology. American Psychological Association, 83(3): 405-410. doi: 10.1037/0022-0663.83.3.405.

5. Efil, I. (2007).Time management. In: L Kucukahmet (Ed.): Classroom Management. Ankara: Nobel Publications.

6. Eid, N. M., Safan, S. M. and Diab, G. M. (2015). The Effect of Time Management Skills and Self Esteem of Students on Their Grade Point Averages (GPA). IOSR Journal of Nursing and Health Science Ver. I, 4(1): 82-88. doi: 10.9790/1959-04118288.

7. Guoging, Y. and Yongxin, Z. (2000). Gender Differences of china's Managers in Time Management. Woman in Management Review, 15(1): 33-40.

8. Indreica, E.S., Cazan, A.M. and Truţa, C. (2011). Effects of learning styles and time management on academic achievement. Procedia - Social and Behavioral Sciences, 30(2011):1096-1102. doi: 10.1016/j.sbspro.2011.10.214.

9. Jahanseir, K., Salehzadeh, K., Vesagi, H. and Mosavifar, A.(2008). A Study of the Effect of Time Management on Academic Achievement of Students of Islamic Azad university Maragheh Branch. Research in curriculum planning. 2008; 1 (16) :97-114

10. Khatib, A.S.A. (2014). Time Management and Its Relation to Students' Stress, Gender and Academic Achievement among Sample of Students at Al Ain University of Science andTechnology, UAE. International Journal of Business and Social Research, 4(5): 47-57.

11. King, J. M. C. (2002). The procrastination syndrome, signs, symptoms, and treatment cultural studies and analysis. Philadelphia: stoke publisher.

12. Koch, R. (1998).The 80/20 Principle: The Secret of Achieving More with Less. New York: Bantam Doubleday Dell Publishing Group.

13. Liu, O. L., Rijmen, F., MacCann, C. and Roberts, R. (2009). The assessment of time management in middle-school students. Personality and Individual Differences, 47(3): 174-179. doi: 10.1016/j.paid.2009.02.018.

14. Macan, T., Gibson, J. M. and Cunningham, J. (2010). Will you remember to read this article later when you have time? The relationship between prospective memory and time management. Personality and Individual Differences. 48(6):725-730. doi: 10.1016/j.paid.2010.01.015.

15. MindTools.com (2017) What Is Time Management? Time Management Skills From MindTools.com. Available at: https://www.mindtools.com/pages/article/newHTE_00.htm (Accessed: 23 January 2017).

16. Misra, R. and McKean, M. (2000). College students' academic stress and its relation to their anxiety, time management, and leisure satisfaction. American Journal of Health Studies., 16(1): 41-51.

17. Oboko, O.A., Theodora, O.E., Oboko, O.O., and Monday, I.B. (2015). Prevalence of stress, stressors and coping strategies among medical students in a Nigerian medical school. African Journal of Medical and Health Sciences, 14(1): 29-34. doi: 10.4103/2384-5589.153384.

18. Pehlivan, A. (2013). The Effect of the Time Management Skills of Students Taking a Financial Accounting Course on their Course Grades and Grade Point Averages. International Journal of Business and Social Science. 4(5): 196-203.

19. Proctor, B. E., Prevatt, F. F. and Adams, K. S. (2006). Study Skills Profiles of Normal-Achieving and AcademicallyStruggling College Students. Journal of College Student Development. 47(1): 37-51. doi: 10.1353/csd.2006.0011.

20. Saketi, P. and Taheri, A. (2010). The Relationship between Time Management and Academic Achievements Among Bachelor and Master Students of Shiraz University and Shiraz University of Medical Sciences. Iranian Journal of Medical Education. 10(3): 293-300.

21. SkillsYouNeed (2017).Time Management Skills | SkillsYouNeed. Available at: http://www.skillsyouneed.com/ps/time-management.html (Accessed: 23 January 2017).

22. Stecker, T. (2004). Well-being in an academic environment. Medical Education, 38(5): 465-478. doi: 10.1046/j.13652929.2004.01812.x.

23. Wayne State University.(2013). Advising-Time Management Questionnaire. Available at: http://advising.wayne.edu/hndbk/time.php (Accessed: 24 January 2017).

24. Waghachavare, V. B., Dhumale, G. B., Kadam, Y. R. and Gore, A. D. (2013). A study of stress among students of professional colleges from an urban area in India. Sultan Qaboos University Medical Journal, 13(3): 422-429.

25. Yousafzai, A. W., Ahmer, S., Syed, E., Bhutto, N., Iqbal, S., Siddiqi, M. N. and Zaman, M. (2009). Well-being of medical students and their awareness on substance misuse: a cross-sectional survey in Pakistan.Annals of general psychiatry, 8, p. 8. doi: 10.1186/1744-859X-8-8. 